IP Periodica Polytechnica Civil Engineering

60(4), pp. 647 660 2016 DOI: $10.3311 /$ PPci.8759

Creative Commons Attribution (1)

RESEARCH ARTICLE

\section{Behaviour of FRP Confined Concrete Cylinders: Experimental Investigation and Strength Model}

\author{
Mahfoud Touhari, Ratiba Mitiche-Kettab
}

Received 04-11-2015, revised 14-02-2016, accepted 17-02-2016

\begin{abstract}
The present paper is devoted to investigate the behaviour of FRP confined concrete cylinders subjected under axial compressive loading. A total of 54 FRP confined concrete cylinders with 2 types of FRP composite wrap, Carbone fiber reinforced polymer (CFRP) and glass fiber reinforced polymer (GFRP), were tested under monotonic axial compression. The effects of several parameters such as unconfined concrete strength, type of FRP composite and number of FRP layers are investigated. Three different concrete mixes were examined, with a compressive strengths average of 26, 40 and $60 \mathrm{MPa}$. The effective circumferential FRP failure strain and the effect of the effective lateral confining pressure were investigated. Peak axial compressive strength and corresponding strain of unconfined and FRP confined concrete cylinders were compared. The obtained results show that the CFRP reinforced cylinders provide a significant increase in ultimate compression stress compared to the GFRP reinforced ones. A new model is presented to predict the compressive axial strength and corresponding strain of FRP confined columns.
\end{abstract}

\section{Keywords}

FRP composite $\cdot$ CFRP $\cdot$ GFRP $\cdot$ compressive strength $\cdot$ ultimate strain - effective circumferential failure $\cdot$ effective lateral confining

\section{Mahfoud Touhari}

Civil Engineering Department, National Polytechnic school of Algiers, 10 BP 182 Avenue Hassen Badi El Harrach 16200, Algeria

e-mail: touhari2001@gmail.com

\section{Ratiba Mitiche-Kettab}

Civil Engineering Department, National Polytechnic school of Algiers, 10 BP 182 Avenue Hassen Badi El Harrach 16200, Algeria

e-mail: miticherdz@yahoo.fr

\section{Introduction}

Fibre-reinforced polymer and Fibre-reinforced plastic (FRP) are composites materials made of a polymer and plastic matrix, respectively, reinforced with fibres. The fibres are usually glass, carbon, or aramid, although other fibres such as paper or wood or asbestos have been sometimes used. The polymer is usually an epoxy or vinylester giving a flexible form whereas the plastic is usually polyester thermosetting plastic giving a hard form. Fiber Reinforced Polymer (FRP) and Fibre-reinforced plastics materials have emerged to be one of the most promising construction materials for reinforcement of concrete members in the last four decades. High tensile strength, High strength-toweight ratio, linear elastic behaviour to failure, unaffected by aggressive environmental conditions, good corrosion resistant properties, minimal effect on shape and size of existing member, non-magnetic and non-conductive and design flexibility are some of the appealing characteristics of FRP materials. Several experimental studies have been principally conducted for estimating the axial strength and stress-strain behaviour of FRP circular confined concrete columns [16, 37, 38]. These studies have investigated most of the critical parameters as the type of FRP material (carbon, aramid, glass, ect.) [32] and its thickness [12], the influence of unconfined concrete strength[10] and the shape of the specimens[17]. Bouchelaghem et all [2] developed a new axial compression technique, consisting in sequential loading of the same sample, with the first load step terminated prior to failure of the column. Ozbakkaloglu [8] presented results of the critical column parameters on the compressive behaviour of CFRP. Furthermore, several models have been developed to predict the strength and strain enhancement of FRP confined concrete columns. Mender et al. [36] proposed a model for concrete confined by transverse steel. Saadatmanesh et al. [30] used the stress-strain model proposed by Mander et al. [27] to analyse the behaviour of concrete columns externally wrapped with FRP composite straps. The model is used to assess the gain in strength and ductility of concrete columns confined by FRP materials. Mirmiran et al. [21] indicated how FRP materials significantly enhance the strength, ductility and durability of concrete columns, this new confinement model was pro- 
posed to quantify the gain in strength of FRP confined concrete columns. Lam et Tang [6] studied on the compressive strength of FRP confined concrete. They reviewed existing FRP confined concrete strength models and proposed a new strength approach for concrete confined by two different types of FRP materials. Ozbakkaloglu and Jian [20] developed a new model based on assessment of different critical column parameters for CFRP and GFRP confined concrete cylinders. Mohammad et all [14] developed a theoretical stress-strain model for circular concrete columns confined by GFRP spirals and hoops.

The majority of models devoted to predict the compressive strength of FRP confined concrete columns are based on the general equation proposed by Richart and al. [31] (equation 1) which has been developed to estimate the confined concrete with steel.

$$
f^{\prime}{ }_{c c}=f^{\prime}{ }_{c o}+k_{1} f_{l}^{\prime}
$$

Where $f^{\prime} c \mathrm{c}$ and $f_{{ }^{\prime}} \mathrm{O}$ are the compressive strength of confined and unconfined concrete, respectively, $f^{\prime} 1$ is the effective lateral confining stress, and $k 1$ is the confinement effectiveness factor.

However, recent studies have revealed that the steel confined concrete existing models give overestimation and can not be used for the concrete confined with PRF materials [3, 7, 15]. Based on the Mohr-Coulomb failure criterion, the real mechanism of confinement with FRP materials and the experiment results, a new model has been proposed in this study.

The present work reports the preliminary results of an experimental study on the behaviour of standard concrete cylinders externally confined with FRP sheets subjected to axial compressive loading. The following objectives were set: (1) evaluation the effectiveness of external FRP confined concrete cylinders; (2) evaluation the effect of the unconfined concrete compressive strength on the behaviour of FRP confined concrete cylinders; (3) evaluation the effect of two different types of FRP materials, Carbone fiber reinforced polymer (CFRP) and glass fiber reinforced polymer (GFRP), and strengthening ratio on the ultimate strength and ductility of confined concrete cylinders; (4) investigation of The effective circumferential FRP failure strain and the effect of the effective lateral confining pressure. Finally, basing on the experiment results, a new confinement model for FRP confined concrete cylinders is proposed.

\section{Experimental investigation}

\subsection{Material properties}

\subsubsection{Concrete}

For the preparation of the specimens used in the present study, three concrete mixtures were used, low-strength (LSC), normalstrength (NSC) and high-strength concrete (HSC), with strength of $25 \mathrm{MPa}, 40 \mathrm{MPa}$, and $60 \mathrm{MPa}$, respectively. The concrete cylinders were casted in the civil engineering department laboratory of national polytechnic school of Algiers using a mechanical mixer. Ordinary Portland Cement was used with wa- ter/cement ratios of $0.59,0.46$, and 0.34 for the LSC, NSC and HSC, respectively. $0.6 \%$ and $1.4 \%$ of Superplasticiser were added at different amounts of mix design NSC and HSC, respectively.

\subsubsection{FRP composites}

The fibers used for the experimental work are:

- Wrap fabric of Carbone fibers, unidirectional;

- Wrap fabric of Glass fibers, unidirectional.

The band between the concrete and the FRP wrap is established by using an adhesive, resin and hardener in which the mixing ratio of the two components by weight was $2 / 1$. The properties of FRP materials and epoxy resin adhesive used for the tests are stated in Table 1 (data are given by the manufacturer).

The mechanical properties, including the modulus, the tensile strength and the elongation at failure were obtained through tensile coupon tests (TCT) of FRP composites are also displayed in Table 1.

\subsection{Fabrication of the concrete specimens and testing pro- cedur}

\subsubsection{Specimen fabrication}

A total of 54 standard confined concrete cylinders of $160 \mathrm{~mm}$ diameter and $320 \mathrm{~mm}$ height were tested under axial compression loading. Two types of FRP jacketing systems CFRP and GFRP labelled with $\mathrm{C}$ and $\mathrm{G}$, respectively, and three mixtures of unconfined concrete cylinders LSC, NSC and HSC labelled with $\mathrm{L}, \mathrm{N}$ and $\mathrm{H}$, respectively, were investigated in this study. All specimens were reinforced with one, two or three layers of FRP materials where the labels 1,2 and 3 identified the number of FRP layers used. For each group of testing parameters, three identical specimens were examined and labelled with A, $\mathrm{B}$ and $\mathrm{C}$. For example, the specimen $\mathrm{CN} 2-\mathrm{B}$ is the second specimen $(B)$ of Normal concrete $(N)$ confined with two layers (2) of CFRP materials $(C)$. The cylinders were cured in water for 28 days at a constant temperature of $25^{\circ} \mathrm{C}$. Table 2 collects the experimental parameters investigated in this study.

\subsubsection{FRP wrapping and testing procedure}

After 28 days of curing, the concrete cylinders were cleaned and totally dried. For each layer of FRP wrap, two plies of epoxy, one on the cylinder surface and the other on the surface of the installed wrap, were applied using paintbrushes to entirely saturate the layers with epoxy. Based on the assumption of Shahawy et al [15] which showed that the last FRP layer was wrapped around the cylinder with an overlap of $1 / 4$ the perimeter to prevent slipping or detachment fiber during testing and ensure the development of the full composite strength, in this study the last FRP layer was wound around the cylinder with an overlap of $130 \mathrm{~mm}$. Specimens were analysed under a monotonic axial 
Tab. 1. Mechanical properties of FRP materials

\begin{tabular}{|c|c|c|c|c|c|}
\hline Material & $\mathrm{E}_{f r p}(\mathrm{GPa})$ & $\begin{array}{c}\text { Tensile strength } \\
\text { (MPa) }\end{array}$ & $\mathrm{t}(\mathrm{mm})$ & Viscosi-ty (mPaS) & $\begin{array}{c}\text { Elongation at failure } \\
(\%)\end{array}$ \\
\hline $\begin{array}{c}\text { CFRP/fiber Sika Wrap } \\
230 \mathrm{C}\end{array}$ & 234 & 3650 & 0.13 & - & 1.8 \\
\hline $\begin{array}{c}\text { GFRP/fiber Sika } \\
\text { Wrap 430G }\end{array}$ & 76 & 2200 & 0.17 & - & 2.8 \\
\hline MEDAPOXY STR & - & 25 & - & 11000 & - \\
\hline $\begin{array}{c}\text { CFRP } \\
\text { composite(TCT) }\end{array}$ & 34 & 403 & 1 & - & 1.4 \\
\hline $\begin{array}{c}\text { GFRP } \\
\text { composite(TCT) }\end{array}$ & 26 & 325 & 1 & - & 1.9 \\
\hline
\end{tabular}

compression load up to failure. Axial and lateral strains were measured using an appreciable extensometer.

The instrumentation incorporated one Extensometer with three radial linear variable differential transducers (LVDTs) positioned in the form of a hoop at the mid-height of the specimens. Moreover, specimens were fitted with an embedded strain gage on mid-height of concrete to measure axial strains in concrete. During testing, an automatic data acquisition system was using for registering the axial loads and corresponding strains. Fig. 1 shows the test setup and the data acquisition system.

\subsection{Results and discussion}

\subsubsection{Overall Behaviour and observed failure modes}

The results of the experimental study are summarized in 0 . The results show that Carbone and glass fiber composite confinement can significantly enhance the ultimate strength and strain of concrete cylinders. For CFRP confined concrete, the specimens exhibited an average gain of $93 \%$ and $523 \%$ in terms of load carrying capacity and ductility, respectively. For specimens of GFRP confined concrete, the average gain was $56 \%$ and $515 \%$ in terms of load carrying capacity and ductility, respectively.

The ultimate strength and strain of FRP confined concrete cylinders increase with the amount of composite wrapping. All the FRP confined concrete specimens failed by the rupture of FRP jacket as a result of hoop tension. During the loading state, crack sounds in the FRP jacket started at approximately $50 \%$ of the ultimate compressive stress. The failure was gradual, and finished with a sudden and explosive noise. The failure mode for all specimens of GFRP confined concrete cylinders was a continuous rupture of the FRP wrap from top to bottom. The rupture of FRP wrap in the CFRP confined concrete cylinders can be divided into two modes, ringed rupture and localised FRP rupture at the lower, mid and top sections. Fig. 2 shows examples of both of these failure modes.

\subsubsection{Stress-strain response}

Representative of stress-strain curves for each series of tested FRP wrapped specimens are represented in Fig. 3. This figure give the axial stress versus the axial and lateral strains for circu-

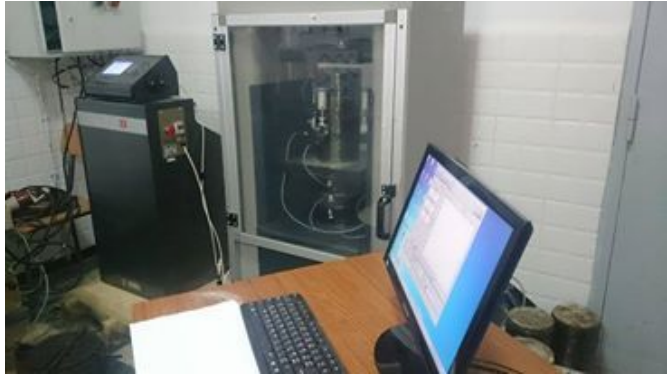

(a)

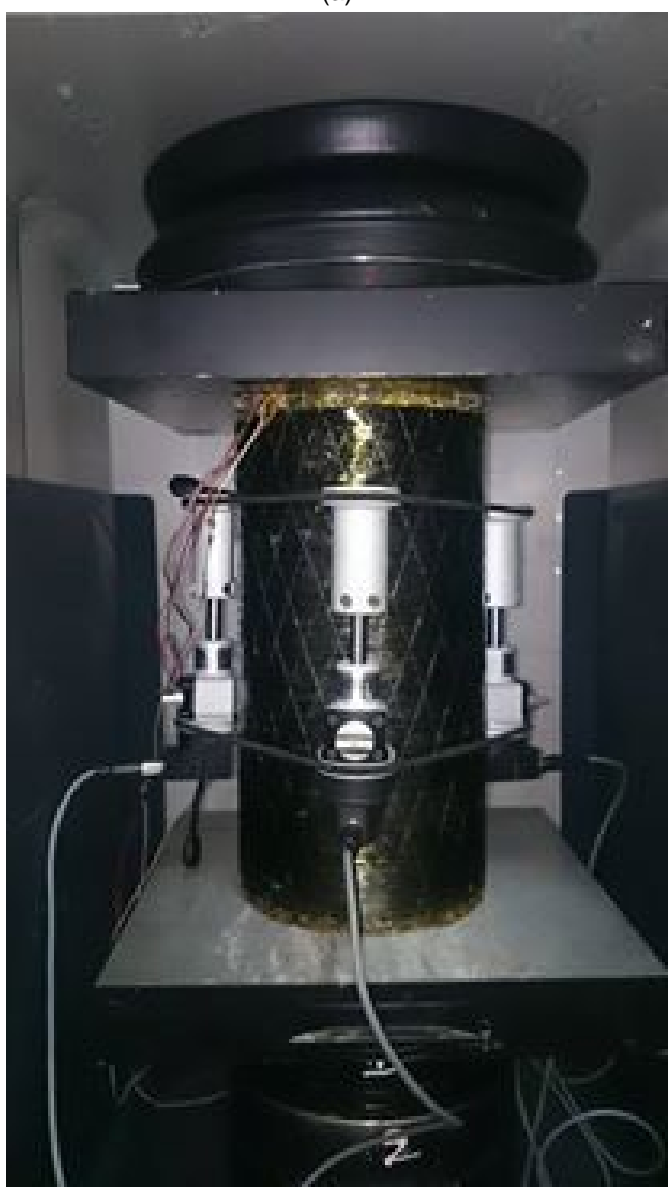

(b)

Fig. 1. (a) data acquisition system (b) test setup 
Tab. 2. Data and results of FRP confined concrete cylinder

\begin{tabular}{|c|c|c|c|c|c|c|c|c|c|c|c|c|c|}
\hline $\begin{array}{c}\text { specimen } \\
\text { Cod }\end{array}$ & $\begin{array}{c}f_{c o}^{\prime} \\
(\mathrm{Mpa})\end{array}$ & $\begin{array}{c}t f \\
(\mathrm{~mm})\end{array}$ & $\begin{array}{c}\text { Efrp } \\
(\mathrm{GPa})\end{array}$ & $\begin{array}{c}\varepsilon_{f r p, u} \\
(\% \circ)\end{array}$ & $\begin{array}{c}\varepsilon_{h, r e p} \\
(\% \circ)\end{array}$ & $\mathrm{Ke}$ & $\begin{array}{c}f_{l, e f f}^{\prime} \\
(\text { Mpa)) }\end{array}$ & $f_{l, e f}^{\prime} f / f^{\prime}{ }^{\prime}$ & $\begin{array}{c}f_{c c}^{\prime} \\
(\mathrm{Mpa})\end{array}$ & $f_{c c}^{\prime} / f^{\prime} c$ & $\varepsilon_{c o}(\% \circ)$ & $\varepsilon_{c c}^{\prime}(\% \circ)$ & $\varepsilon^{\prime} c / \varepsilon^{\prime} c$ \\
\hline CL1- & 24 & & 34 & 14 & 12.7 & 0.91 & 5.41 & 0.22 & 47.0 & 1.96 & 2.71 & 16.9 & 6.25 \\
\hline CL1- & 24 & & 34 & 14 & 12.6 & 0. & 5.35 & 0.22 & 45.3 & 1.89 & 2.71 & 15.6 & 5.78 \\
\hline CL1- & 24 & & 34 & 14 & 5.11 & 0.37 & 2.17 & 0.09 & 29.5 & 1.23 & 2.71 & 9.31 & 3.43 \\
\hline CL2- & 24 & & 34 & 14 & 11.9 & 0.86 & 10.1 & 0.42 & 55.8 & 2.32 & 2.71 & 24.1 & 8.91 \\
\hline CL2- & 24 & & 34 & 14 & 12.3 & 0.88 & 10.5 & 0.43 & 55.5 & 2.31 & 2.71 & 21.8 & 8.07 \\
\hline CL2- & 24 & & 34 & 14 & 12.5 & 0. & 10.6 & 0.44 & 58.0 & 2.41 & 2.71 & 25.2 & 9.32 \\
\hline CL3- & 24 & & 34 & 14 & 11.4 & 0.82 & 14.5 & 0.60 & 77.3 & 3.22 & 2.71 & 32.0 & 11.830 \\
\hline CL3- & 24 & & 34 & 14 & 11.6 & 0.83 & 14.7 & 0.61 & 79.0 & 3.29 & 2.71 & 33.4 & 12.3 \\
\hline CL3- & 24 & & 34 & 14 & 10.8 & 0.77 & 13.8 & 0.57 & 72.9 & 3.03 & 2.71 & 29.1 & 10.7 \\
\hline CN1- & 41.6 & & 34 & 14 & 6.69 & 0.48 & 2.84 & 0.06 & 49.8 & 1.19 & 3.11 & 9.92 & 3.19 \\
\hline CN1- & 41.6 & & 34 & 14 & 11.6 & 0.83 & 4.94 & 0.11 & 61.3 & 1.47 & 3.11 & 12.5 & 4.03 \\
\hline CN1- & 41.6 & & 34 & 14 & 12.1 & 0.86 & 5.14 & 0.12 & 62.9 & 1.51 & 3.11 & 12.9 & 4.17 \\
\hline CN2- & 41.6 & & 34 & 14 & 10.0 & 0.72 & 8.54 & 0.20 & 73.2 & 1.76 & 3.11 & 15.7 & 5.07 \\
\hline CN2- & 41.6 & & 34 & 14 & 11.8 & 0.85 & 10.0 & 0.24 & 76.6 & 1.84 & 3.11 & 18.4 & 5.94 \\
\hline CN2- & 41.6 & & 34 & 14 & 11.9 & 0.85 & 10.1 & 0.24 & 77.0 & 1.85 & 3.11 & 19.9 & 6.40 \\
\hline CN3- & 41.6 & & 34 & 14 & 11.4 & 0.82 & 14.5 & 0.35 & 96.9 & 2.33 & 3.11 & 25.2 & 8.11 \\
\hline CN3- & 41.6 & & 34 & 14 & 11.1 & 0. & 14.2 & 0.34 & 95.9 & 2.30 & 3.11 & 23.0 & 7.41 \\
\hline CN3- & 41.6 & & 34 & 14 & 10.8 & 0.78 & 13.8 & 0.33 & 92.7 & 2.23 & 3.11 & 22.4 & 7.21 \\
\hline $\mathrm{CH} 1-$ & 61.5 & & 34 & 14 & 11.9 & 0.85 & 5.08 & 0.08 & 80.0 & 1.30 & 3.02 & 10.9 & 3.63 \\
\hline $\mathrm{CH} 1-$ & 61.5 & & 34 & 14 & 10.6 & 0.76 & 4.54 & 0.07 & 78.9 & 1.28 & 3.02 & 9.78 & 3.23 \\
\hline $\mathrm{CH} 1-$ & 61.5 & & 34 & 14 & 11.7 & 0.84 & 4.99 & 0.08 & 81.1 & 1.31 & 3.02 & 9.72 & 3.21 \\
\hline $\mathrm{CH} 2-$ & 61.5 & & 34 & 14 & 10.8 & 0.78 & 9.25 & 0.15 & 96.0 & 1.56 & 3.02 & 11.6 & 3.86 \\
\hline $\mathrm{CH} 2-$ & 61.5 & & 34 & 14 & 11.1 & 0. & 9.46 & 0.15 & 99.4 & 1.61 & 3.02 & 13.7 & 4.56 \\
\hline $\mathrm{CH} 2-$ & 61.5 & & 34 & 14 & 11.9 & 0.85 & 10.1 & 0.16 & 98.2 & 1.59 & 3.02 & 14.9 & 4.94 \\
\hline CH3- & 61.5 & & 34 & 14 & 9.26 & 0.66 & 11.8 & 0.19 & 104.99 & 1.70 & 3.02 & 15.6 & 5.18 \\
\hline CH3- & 61.5 & & 34 & 14 & 11.8 & 0.85 & 15.1 & 0.24 & 117.14 & 1.90 & 3.02 & 17.8 & 5.92 \\
\hline $\mathrm{CH} 3-$ & 61.5 & & 34 & 14 & 10.1 & 0.72 & 12.9 & 0.21 & 105.44 & 1.71 & 3.02 & 15.9 & 5.29 \\
\hline GL1- & 26.2 & & 26 & 19 & 14.8 & 0.78 & 4.83 & 0.18 & 38.3 & 1.46 & 2.67 & 15.0 & 5.63 \\
\hline GL1- & 26.2 & & 26 & 19 & 14.5 & 0.76 & 4.71 & 0.18 & 34.6 & 1.32 & 2.67 & 12.6 & 4.73 \\
\hline GL1- & 26.2 & & 26 & 19 & 15.0 & 0.79 & 4.87 & 0.18 & 38 & 1.45 & 2.67 & 13.9 & 5.21 \\
\hline GL2- & 26.2 & & 26 & 19 & 2.87 & 0.15 & 1.86 & 0.07 & 30.2 & 1.15 & 2.67 & 6.81 & 2.55 \\
\hline GL2- & 26.2 & & 26 & 19 & 14.5 & 0.76 & 9.42 & 0.36 & 49.4 & 1.88 & 2.67 & 24.1 & 9.04 \\
\hline GL2- & 26.2 & & 26 & 19 & 15.0 & 0.79 & 9.75 & 0.37 & 52.5 & 2.00 & 2.67 & 25.5 & 9.56 \\
\hline GL3- & 26.2 & & 26 & 19 & 14.0 & 0.74 & 13.709 & 0.52 & 62.8 & 2.39 & 2.67 & 33.9 & 12.7 \\
\hline GL3-B & 26.2 & & 26 & 19 & 13.0 & 0.68 & 12.7 & 0.48 & 56.4 & 2.15 & 2.67 & 29.8 & 11.1 \\
\hline GL3- & 26.2 & & 26 & 19 & 12.9 & 0.68 & 12.6 & 0.48 & 54.7 & 2.09 & 2.67 & 28.9 & 10.8 \\
\hline GN1- & 42.6 & & 26 & 19 & 14.3 & 0.75 & 4.66 & 0.11 & 56.5 & 1.32 & 2.89 & 11.0 & 3.81 \\
\hline GN1- & 42.6 & & 26 & 19 & 14.0 & 0.73 & 4.55 & 0.10 & 55.5 & 1.30 & 2.89 & 10.4 & 3.61 \\
\hline GN1- & 42.6 & & 26 & 19 & 16.3 & 0.86 & 5.31 & 0.12 & 59.8 & 1.40 & 2.89 & 12.3 & 4.26 \\
\hline GN2- & 42.6 & & 26 & 19 & 14.6 & 0.77 & 9.52 & 0.22 & 68.5 & 1.60 & 2.89 & 16.5 & 5.74 \\
\hline GN2- & 42.6 & & 26 & 19 & 14.7 & 0.77 & 9.60 & 0.22 & 70.0 & 1.64 & 2.89 & 17.2 & 5.96 \\
\hline GN2- & 42.6 & & 26 & 19 & 15.0 & 0.79 & 9.77 & 0.22 & 71.7 & 1.68 & 2.89 & 18.1 & 6.28 \\
\hline GN3- & 42.6 & & 26 & 19 & 14.0 & 0.73 & 13.6 & 0.32 & 75.5 & 1.77 & 2.89 & 21.0 & 7.29 \\
\hline GN3- & 42.6 & & 26 & 19 & 15 & 0.78 & 14.6 & 0.34 & 78.8 & 1.85 & 2.89 & 24.9 & 8.62 \\
\hline GN3- & 42.6 & & 26 & 19 & 14.3 & 0.75 & 13.9 & 0.32 & 77.5 & 1.82 & 2.89 & 22.4 & 7.77 \\
\hline GH1- & 61.7 & & 26 & 19 & 12.9 & 0.68 & 4.20 & 0.06 & 69.4 & 1.12 & 3.11 & 8.85 & 2.84 \\
\hline GH1- & 61.7 & & 26 & 19 & 14.5 & 0.76 & 4.71 & 0.07 & 73.1 & 1.18 & 3.11 & 9.37 & 3.01 \\
\hline GH1- & 61.7 & & 26 & 19 & 16.0 & 0.84 & 5.20 & 0.08 & 77.5 & 1.25 & 3.11 & 11.1 & 3.58 \\
\hline $\mathrm{GH}_{2}-$ & 61.7 & & 26 & 19 & 15.0 & 0.79 & 9.78 & 0.15 & 80.8 & 1.31 & 3.11 & 14.9 & 4.80 \\
\hline GH2- & 61.7 & & 26 & 19 & 14.2 & 0.74 & 9.23 & 0.15 & 76.7 & 1.24 & 3.11 & 13.5 & 4.37 \\
\hline GH2- & 61.7 & & 26 & 19 & 14.8 & 0.78 & 9.67 & 0.15 & 78.0 & 1.26 & 3.11 & 14.4 & 4.65 \\
\hline GH3- & 61.7 & & 26 & 19 & 13.5 & 0.71 & 13.1 & 0.21 & 90.1 & 1.46 & 3.11 & 17.1 & 5.51 \\
\hline GH3- & 61.7 & & 26 & 19 & 14.2 & 0.74 & 13.8 & 0.22 & 92.1 & 1.49 & 3.11 & 18.8 & 6.07 \\
\hline GH3- & 61.7 & & 26 & 19 & 15.0 & 0.79 & 14.6 & 0.23 & 94.4 & 1.53 & 3.11 & 19.5 & 6.28 \\
\hline
\end{tabular}




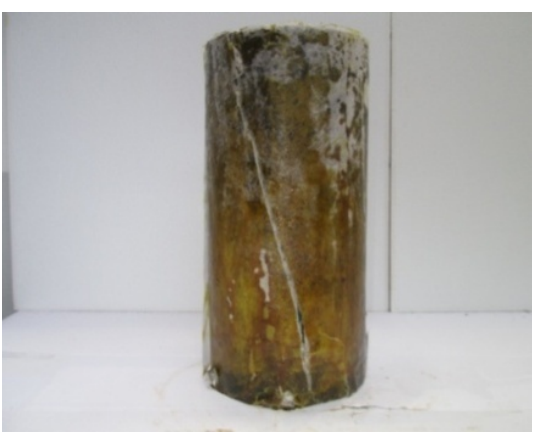

(a)

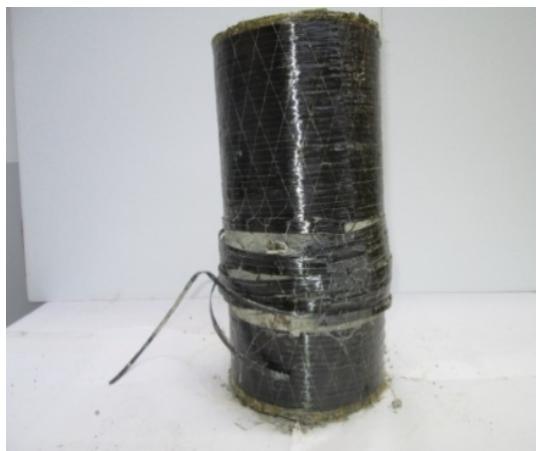

(d)

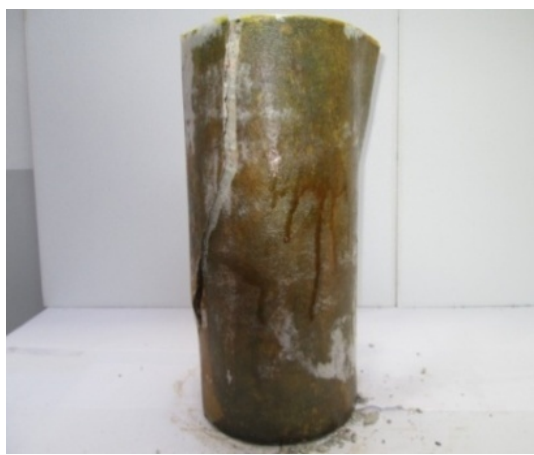

(b)

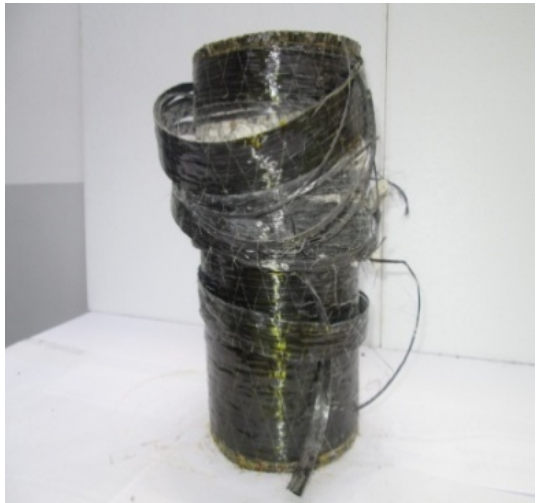

(e)

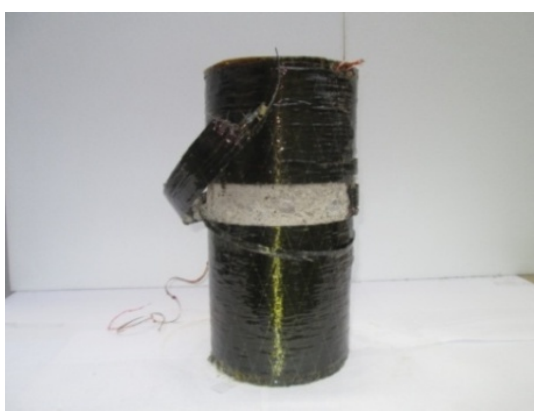

(c)

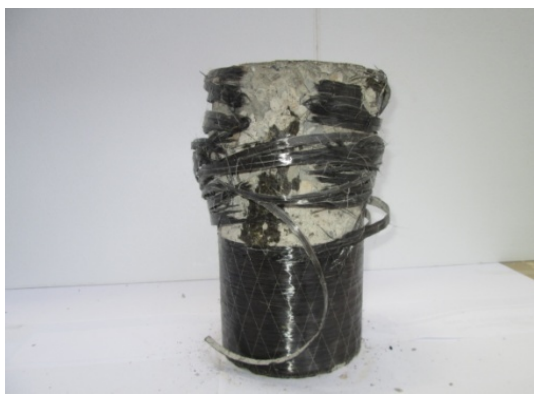

(f)
Fig. 2. Typical failure of FRP wrapped specimens: (a) and (b) rupture of the GFRP wraps from top to bottom, (c) ringed rupture of CFRP wraps, (d) localised
CFRP rupture at the lower section, (e) localised CFRP rupture at the top section, (f) localised CFRP rupture at the mid section. lar confined concrete cylinders with one, two and three layers of CFRP and GFRP wrap. All FRP confined specimens showed a typical bilinear trend. The stress-strain behaviour of FRP confined concrete cylinders is largely dependent to the amount of FRP confinement, where the observed stress-strain response of FRP confined concrete can be divided into three distinct zones.

The first zone is approximately linear response governed by the stiffness of the unconfined concrete, which indicates that no confinement is activated in the FRP wraps. The FRP wraps is activated after reaching the maximum strength of unconfined concrete and applies a continuous increasing pressure on the concrete core until the rupture of FRP confined concrete cylinders. The second zone is nonlinear as a transition zone. In second zone, lateral strain increases and the wrap is activated, this zone occurs shortly after the peak strength of the unconfined concrete has been reached, accompanied with the growth of micro-cracks. Finally, in the third zone, the concrete is entirely cracked and the FRP confinement is activated to provide additional load-carrying capacity by keeping the concrete core intact.

In this point, the stress-strain curve increases with a constant slope up to failure meaning the elastic linearity of FRP wrap stress-strain behaviour. It can be seen from the stress-strain curves that the lateral stress-strain responses were found to be less consistent between the identical specimens compared with the axial stress-strain responses.

In Fig. 4, typical stress-strain responses of FRP confined con- crete cylinders are shown, points $\mathrm{A}$ and $\mathrm{C}$ are the ultimate status of unconfined concrete and FRP confined concrete cylinder, respectively. Point B is located in the second part of the graphs which is the transition point for the stress-strain response, but it is difficult to locate it accurately.

\subsubsection{FRP circumferential failure strain}

The ultimate condition of FRP confined concrete cylinders refers to its compressive strength and ultimate axial strain. According to the obtained test results, the circumferential failure strains were always observed at strain lower than the ultimate strain capacities $\varepsilon_{f r p, u}$ recorded from tensile strain coupon tests. Indicated in 0 , for example, the rupture of the CFRP low strength confined concrete cylinder CL1-B was reached at a maximum effective failure strain $\varepsilon_{h \text {,rep }}$ of $12.61 \%$ ocorresponds to $90 \%$ of the ultimate composite strain $\varepsilon_{f r p, u}(14 \%$ o).

Several possible causes that may explain this strain reduction of the FRP composite can be attributed as to reported in literature [7, 20]: (i) the quality of the workmanship; (ii) the curved shape of the composite wrap or misalignment of fibers may decrease the FRP axial strength, (iii) Near failure the concrete is internally cracked resulting in non homogenous deformations, due to this non homogenous deformations and high loads applied on the cracked concrete, local stress concentration may occur in the FRP reinforcement. So the circumferential failure strain FRP is one of the important factors to be able to predict the strength and strain gains in FRP confined concrete. 

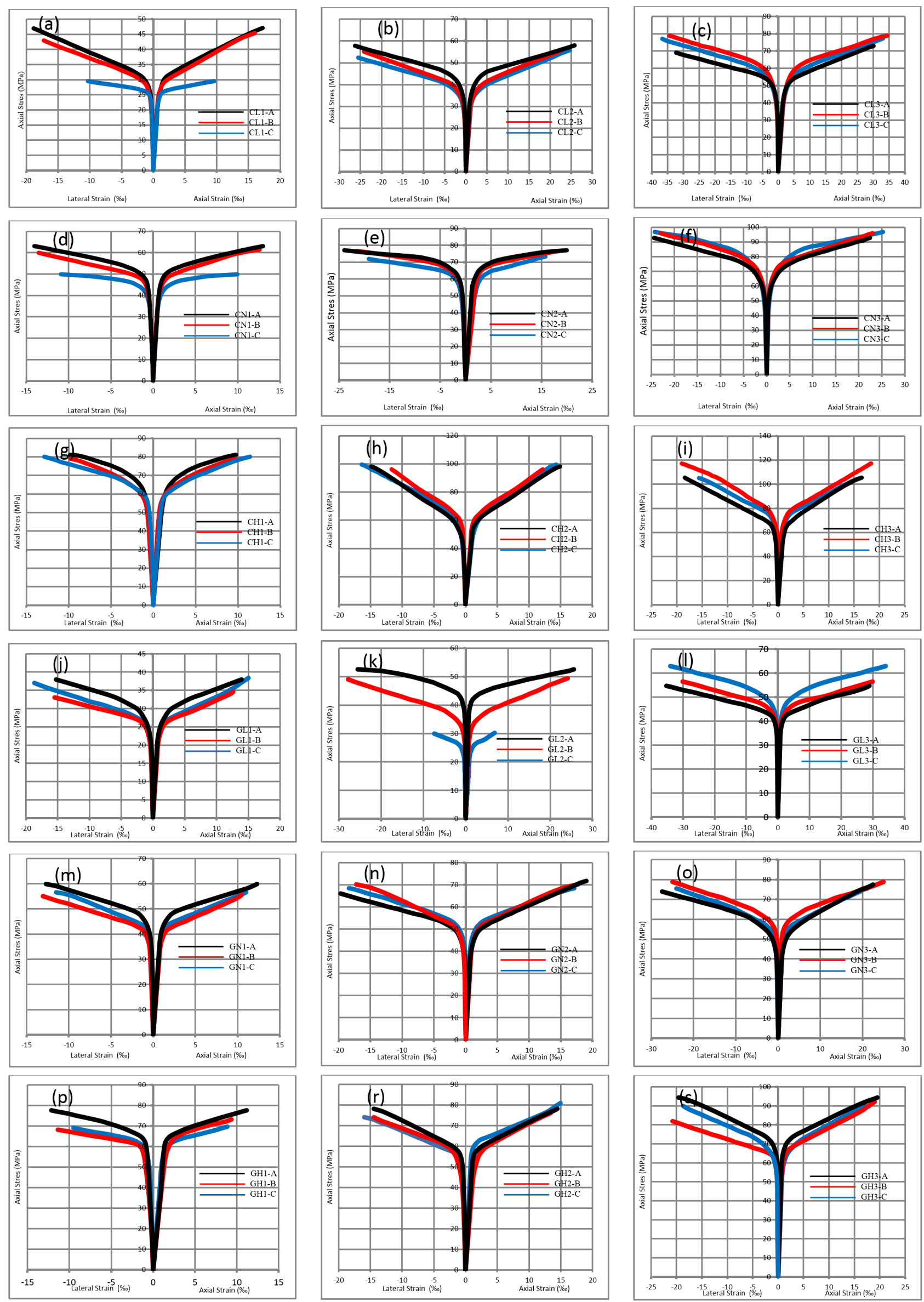

Fig. 3. Experimental stressstrain curves of FRP confined concrete concrete CH2, (i) CH3, (j) GL1, (k) GL2, (1) GL3, (m) GN1, (n) GN2, (o) GN3, (p) GH1, cylinders: (a) CL1, (b) CL2, (c) CL3, (d) CN1, (e) CN2, (f) CN3, (g) CH1, (h) (r) GH2, (s) GH3. 


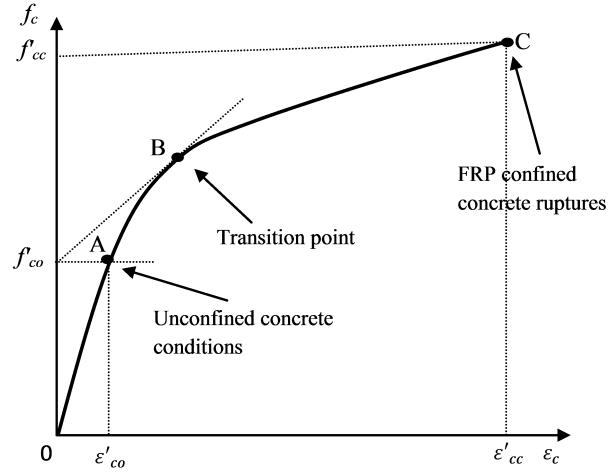

Fig. 4. Typical stress-strain responses for FRP confined concrete

\subsubsection{Effect of concrete strength type}

From the results indicated in 0 , it could be noted that, the CFRP and GFRP confinement on LSC specimens produced higher results in terms of strength and strain than that those of NSC and HSC concrete similar cylinders. For example, the CFRP low-strength confined concrete cylinders where the one layer reinforcement specimen revealed an increase of $69 \%$ and $416 \%$ in terms of compressive strength and axial strain over the reference specimen, respectively. The normal strength concrete cylinders similarly confined, the specimen exhibited an increase of $40 \%$ in compressive strength and $280 \%$ in axial strain. However, in high-concrete cylinders, the specimen exhibited an increase of $31 \%$ in compressive strength and $237 \%$ in axial strain. For one layer of GFRP, the gain in terms of strength capacity of LSC, NSC and is HSC about 41\%, 35\% and 19\%, respectively. The gain in terms of ductility of LSC, NSC and HSC is about 519\%, 390\% and 315\%, respectively. Fig. 5 and Fig. 6 show that the gain in strengths and strains of high and normal strength FRP confined concrete cylinders is much less than those observed in the case of low strength ones, the increase of load capacity and ductility is always higher for the case of lower unconfined concrete strength. $g$ It can be seen that the axial strength and strain enhancement ratios of FRP confined concrete cylinders decrease as the strength of unconfined concrete increases. In other words, higher concrete compressive strength reduces the effect of confinement for the same number of FRP layers. This might be because the more is the strength of concrete; the less is the water cement ratio.

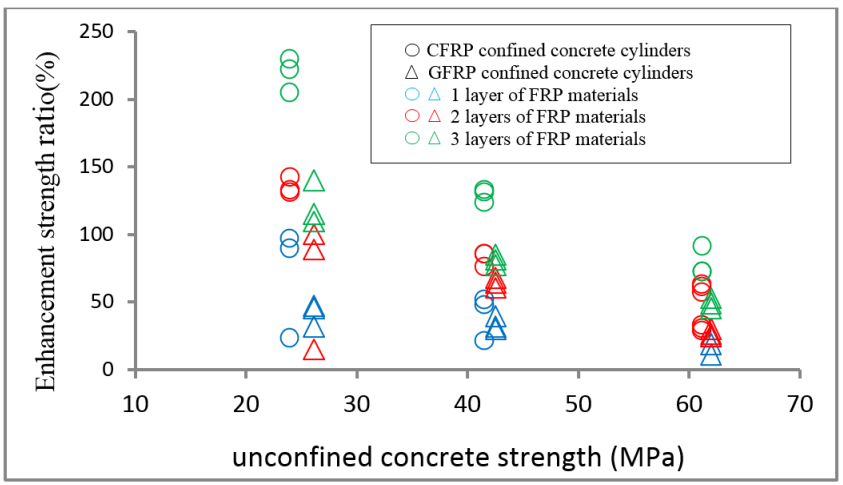

Fig. 5. Effect of concrete strength type on the strength enhancement ratio

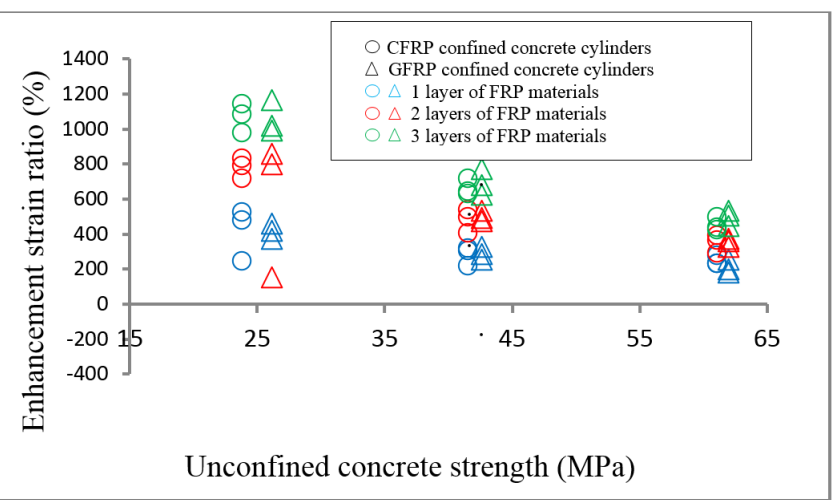

Fig. 6. Effect of concrete strength type on the enhancement strain ratio

Consequently, concrete with higher compressive strength exhibits lower lateral expansion under compression compared to concrete with lower compressive strength. Since the confining action of FRP sheets depends on the lateral expansion of concrete, higher concrete compressive strength reduces the effect of confinement. As a result, the density of the cement matrix increases which prevents the formation of vertical compression cracks until significantly high load occurs [4].

\subsubsection{Effect of the type of FRP material and strengthening ratio}

Fig. 10 and Fig. 11 show that the ultimate compressive strengths $\left(f_{c c}^{\prime}\right)$ and corresponding strains $\left(\varepsilon_{c c}\right)$ are significantly influenced by the type of FRP material. CFRP jacketing attains higher strength and strain than that of GFRP confined specimens, signficate the effect of the mechanical properties of FRP materials on the the strength and strains enhancement ratios. It can be seen that the higher the modulus of the FRP material, the better the confinement of the concrete cylinders. Fig. 7 and Fig. 8 show that the amount of FRP material significantly influences the strength and strain enhancement ratios. In addition, the difference in strength between CFRP confined cylindrical specimens and GFRP ones increases more and more with the increase in the number of layers of FRP. As estimated, the enhancement in strength and strain of FRP confined concrete cylinders is not proportional to the number of FRP layers, especially when high strengthening ratio is used.

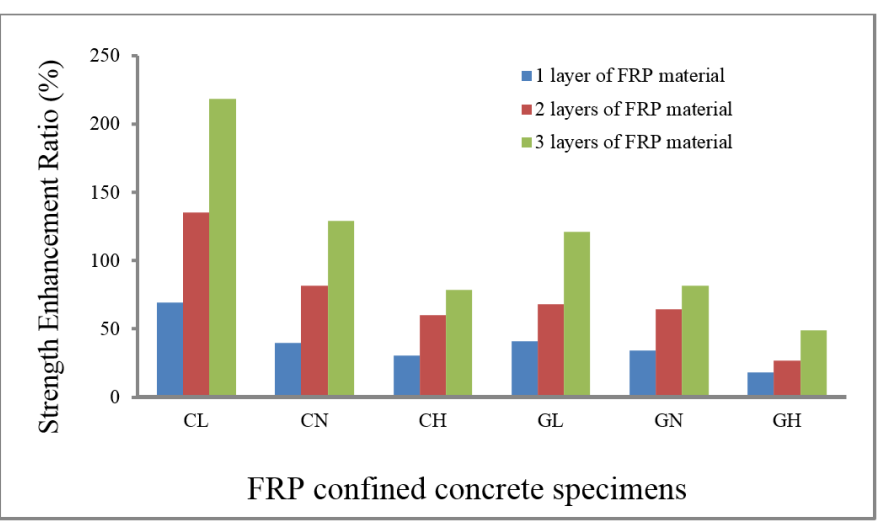

Fig. 7. Effect of strengthening ratio on the FRP confined concrete cylinders strength enhancement 


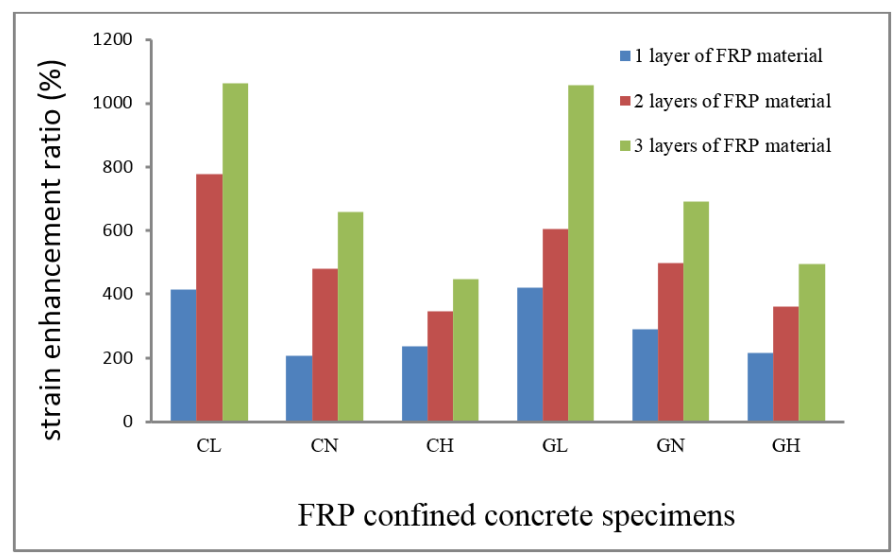

Fig. 8. Effect of strengthening ratio on FRP confined concrete cylinders strain enhancement

\section{Analytical part}

\subsection{Peak axial strength}

\subsubsection{Existing model}

Number of models have been suggested to investigate the FRP confinement effect on the behaviour of concrete columns. Tang et al. [24] classified them as design oriented models and analysis oriented models. The design oriented models are normally in simple closed form (Lam and Tang [7] Nicola et all [11]) and the analysis oriented models predict the stress-strain behaviour using iterative process (Spoelstra and Monti [1], Jiang and Tang [9]). The first well-known study on the stress-strain curve of concrete with and without steel confinement was conducted by Richart et al [31]. The following well known relation was based on a linear relationship for expressing the enhancement of compressive strength based on their test results (Equation (11)). Since then, there have been numerous analytical models presented in the literature that employ Eq. (1) which have been based either on tests of plain concrete specimens or reinforced concrete columns. Most of these models used a constant value for $k_{1}$ and it was limited to between 2 and 5 [6, 12, 18, 35] Moreover, other researchers expressed $k_{1}$ in a non-linear form [14, 26-28].

Fardis and Khalil [35] developed a linear relationship between the ultimate strength and the effective lateral confining stress.

$$
f^{\prime}{ }_{c c}={f^{\prime}}_{c o}+4.1 f_{l}^{\prime}
$$

Mander, Priestley and Park [36] also derived a non-linear relationship between the ultimate strength and the effective lateral confining pressure of confined concrete cylinders based on the tri-axial test data. The MPP model is the most widely used.

$$
{f^{\prime}}^{\prime}{ }_{c c}={f^{\prime}}^{\prime}\left[-1.254+2.254 \times \sqrt{1+\frac{7.94 \times f_{l}^{\prime}}{f_{c o}^{\prime}}-2 \frac{f_{l}^{\prime}}{f_{c o}^{\prime}}}\right]
$$

Li et al. [13] proposed a constitutive model for confined concrete columns reinforced with CFRP materials. They studied the behaviour of cylinders with various strengths of concrete:

$$
f^{\prime}{ }_{c c}=f_{c o}^{\prime}+f_{l}^{\prime} \tan ^{2}\left(45^{0}+\emptyset / 2\right)
$$

$$
\emptyset=36^{o}+1^{o}\left(\frac{f_{o}^{\prime}}{35}\right) \leq 45^{\circ}
$$

where $\emptyset$ is the angle of internal friction of concrete.

Ozbakkaloglu and Jian [20] developed a new model based on over 500 experimental results for CFRP and GFRP confined concrete cylinders:

For CFRP confined concrete cylinders:

$$
\frac{f_{c c}^{\prime}}{f_{c o}^{\prime}}=1+3.64 \frac{f_{l u, a}^{\prime}}{f_{c o}^{\prime}}
$$

For CFRP confined concrete cylinders:

$$
\frac{f_{c c}^{\prime}}{f_{c o}^{\prime}}=1+2.64 \frac{f_{l u, a}^{\prime}}{f_{c o}^{\prime}}
$$

Where $f_{l u, a}^{\prime}$ is the effective lateral confining stress.

Pham and Hadi [33] proposed new confinement model for FRP confined normal- and high-strength concrete circular columns

$$
f_{c c}^{\prime}=0.7 f_{c o}^{\prime}+1.8 f_{l}^{\prime}+5.7 \frac{t}{D}+13
$$

So, there are a few approaches to develop an equation for strength enhancement of confined concrete. All of the above models assumed that the compressive strength of confined concrete is a function of the unconfined concrete strength and the effective lateral confining pressure.

\subsection{Proposed strength mode}

\subsubsection{Mechanism of confinement}

The lateral confinement pressure provided by a FRP jacket to concrete is naturally passive. In FRP confined concrete cylinders, the concrete core extends laterally and this expansion is restrained by the FRP material when it is subjected to an axial compression load. This pressure produces a circular tension resultant in the envelope. The action of expansion and the reaction of the confinement are represented by a uniform lateral pressure $f_{l}$ in the interface and the response of FRP material (Fig. 9). This expansion of the concrete core is confined by the FRP jackets, and thus transforms the concrete core to a 3-D compressive stress condition. The mechanism of confinement goes from uniaxial loading to tri-axial loading.

The maximum confinement pressure is reached when the circumferential strain in the FRP reaches its ultimate strain $\varepsilon_{f r p}$ corresponding to the failure of the cylinder. Based on static analysis, equilibrium of forces, deformation compatibility, and by considering one unit length section along the column span, the forces acting on the section shown in Fig. 9 can be written as:

$$
D f_{l}^{\prime}=2 t_{f} f_{f r p, u}
$$


The lateral confining pressure reaches its maximum value $f_{l}^{\prime}$ at the rupture of FRP, with:

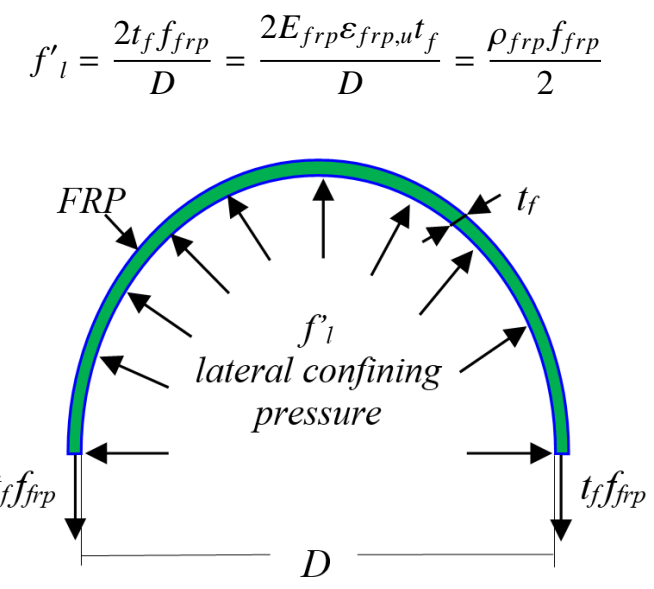

Fig. 9. Mechanism of confinement

In these relations, $f_{l}^{\prime}$ presents the lateral confining pressure, $E_{f r p}$ is the tensile modulus of FRP composite material, $t_{f}$ is the thickness of the composite jacket, $\varepsilon_{f r p, u}$ is the ultimate circumferential strain in the composite jacket, $D$ is the diameter of the concrete core and $\rho_{f r p}$ is the FRP volumetric ratio which is given by the following equation for entirely wrapped circular cross section:

$$
\rho_{f r p}=\frac{4 t_{f}}{D}
$$

\subsubsection{The Mohr-Coulomb failure criterion and Effective FRP strain factor}

The mechanisms of the tri-axial of the soil or rock and the mechanism of the concrete confined with FRP wraps are very similar. According to the Mohr-Coulomb failure criterion, the strength of concrete under a tri-axial stress can be written [5] :

$$
f_{c c}^{\prime}=f_{c o}^{\prime}+\frac{1+\sin \emptyset}{1-\sin \emptyset} f^{\prime}{ }_{l}
$$

where $\emptyset$ is the angle of internal friction of concrete and $f_{l}^{\prime}$ is the lateral confinement pressure.

Generally, it is very intricate to estimate the angle of internal friction at the time of full expansion of lateral confining stress. Bieniawski [25] has developed an empirical failure criterion:

$$
\frac{f_{c c}^{\prime}}{f_{c o}^{\prime}}=1+N\left(\frac{f_{l}^{\prime}}{f_{c o}^{\prime}}\right)^{M}
$$

The constants $N$ and $M$ will be determined by fitting a curve to the family of points:

$$
\left(\frac{f_{l}^{\prime}}{f_{c o}^{\prime}} \frac{f_{c c}^{\prime}}{f_{c o}^{\prime}}-1\right)
$$

As mentioned earlier, the effective FRP failure strain when confined concrete cylinders are reaching the ultimate state is lower than the ultimate FRP tensile strain $\varepsilon_{f r p, u}$. Therefore, the proposed effective FRP strain factor, $k_{e f}$, accounts the ratio of in-situ wrap rupture strains observed in tests of FRP confined concrete cylinders and those observed in tensile coupon test, that is:

$$
k_{e f}=\frac{\varepsilon_{h, r e p}}{\varepsilon_{f r p, u}}
$$

Using Eq. (14), Eq. (10) can be rewritten as:

$$
f^{\prime}{ }_{l}=\frac{2 t_{f} f_{f r p}}{D}=\frac{2 E_{f r p} \varepsilon_{h, r e p} t_{f}}{D} \times \frac{1}{k_{e f}}=\frac{f_{l, e f f}^{\prime}}{k_{e f}}
$$

where $f_{l, e f f}^{\prime}$ is the effective lateral confining pressure corresponding to a maximum effective failure strain $\varepsilon_{h, r e p}$.

Substituting Eq. 15] into Eq. (13), this latter becomes:

$$
\frac{f^{\prime}{ }_{c c}}{f^{\prime}{ }_{c o}}=1+N k_{e f}^{M}\left(\frac{f_{l, e f f}^{\prime}}{f_{c o}^{\prime}}\right)^{M}
$$

$k_{e f}$ is referred to in this article, as the effective FRP strain factor.

\subsubsection{Proposed equation regression}

The average hoop strain in FRP wraps at rupture in FRP confined concrete cylinders can be much lower than that given by tensile coupon tests, meaning the theoretical assumption that the FRP confined concrete cylinder ruptures when the FRP material tensile strength attained at its maximum is not suitable. Based on this observation, the effective peak strength and corresponding strain formula for concrete confined by FRP must be based on the effective hoop rupture strain composite materials.

Based on the empirical failure criterion of Bieniawski [25] and the experimental results reported in 0 , a new model is proposed to predict the peak axial strength of CFRP and GFRP confined concrete cylinders. Fig. 10 shows the relation between the effective confinement ratio $f_{l, e f f}^{\prime} / f_{c o}^{\prime}$ and the strengthening ratio $f_{c c}^{\prime} / f_{c o}^{\prime}$ for the cylinders of the test series. The trend lines of these data shown that the effective pressure determining failure of cylindrical concrete specimens can be closely approximated using these following equations:

For CFRP confined concrete cylinders:

$$
\frac{f^{\prime}{ }_{c c}}{f^{\prime}{ }_{c o}}=1+3.58\left(\frac{f_{l, e f f}^{\prime}}{f_{c o}^{\prime}}\right)^{0.997}
$$

For GFRP confined concrete cylinders:

$$
\frac{f^{\prime}{ }_{c c}}{f^{\prime}{ }_{c o}}=1+2.5\left(\frac{f_{l, e f f}^{\prime}}{f_{c o}^{\prime}}\right)^{1.027}
$$

Using the empirical failure criterion of Bieniawski in the CFRP and GFRP concrete confined concrete cylinders, the constant $M$ is equal to 1 .

It can be seen that, when all specimens of the present study are considered together, the mean effective FRP strain factor $k_{m e f}$ has a value closer to 0.79 and 0.74 for CFRP and GFRP confined concrete cylinders, respectively. Using the mean effective FRP strain factor $k_{m e f}$, with substitution of $f_{l, e f f}^{\prime}$ by $f_{l}^{\prime}$ into Eq. 17) 


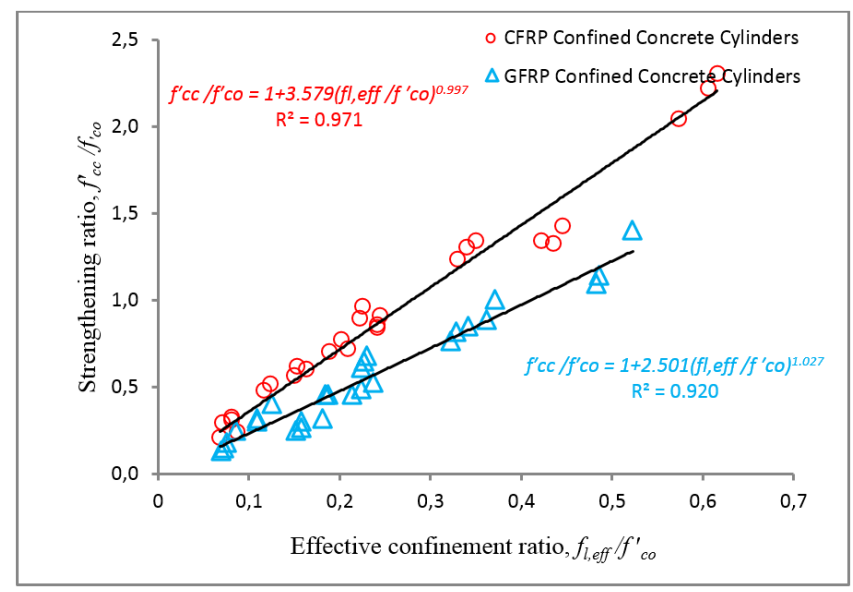

Fig. 10. Strengthening ratio vs. Effective confinement ratio

and Eq. [18, the ultimate strengthening ratio of FRP confined concrete cylinders takes the forms:

For CFRP confined concrete cylinders:

$$
\frac{f^{\prime}{ }_{c c}}{f^{\prime}{ }_{c o}}=1+2.8 \frac{f_{l}^{\prime}}{f_{c o}^{\prime}}
$$

For GFRP confined concrete cylinders:

$$
\frac{f_{c c}^{\prime}}{f^{\prime}{ }_{c o}}=1+1.85 \frac{f_{l}^{\prime}}{f_{c o}^{\prime}}
$$

\subsection{Ultimate axial strain of FRP confined cylinder}

\subsubsection{Existing model}

For FRP confined concrete cylinders, numerous studies suggested that the ultimate axial strain can be correlated to the lateral confining pressure [4, 7, 12]. Existing models can be classified into two categories, empirical or analytical models and numerical models or plasticity analysis. Richart et al. [31] proposed that the effectiveness in the enhancement of axial strain in the FRP confined concrete cylinders is around 5 times that in the enhancement of axial stress:

$$
\frac{\varepsilon_{c c}^{\prime}}{\varepsilon_{c o}^{\prime}}=1+k_{2} \frac{f_{l}^{\prime}}{f_{c o}^{\prime}}
$$

where $k_{2}=5 k_{1}$

From Shehata et al. [23], the strain enhancement ratio FRP confined concrete can be written:

$$
\frac{\varepsilon_{c c}^{\prime}}{\varepsilon_{c o}^{\prime}}=1+6.32\left(\frac{f_{l}^{\prime}}{f_{c o}^{\prime}} \times \frac{f_{c c}^{\prime}}{f_{c o}^{\prime}}\right)
$$

where $\varepsilon_{c o}$ is the strain of unconfined concrete and $\varepsilon_{c c}$ is the ultimate strain of FRP confined concrete.

From Lam et Tang [7], the strain enhancement ratio FRP confined concrete can be written:

$$
\frac{\varepsilon_{c c}^{\prime}}{\varepsilon_{c o}^{\prime}}=1.75+5.53\left(\frac{f_{l}^{\prime}}{f_{c o}^{\prime}}\right)\left(\frac{\varepsilon_{f r p}}{\varepsilon_{c o}}\right)^{0.45}
$$

where $\varepsilon_{f r p}$ is the ultimate tensile strain of FRP material.
From Ozbakkaloglu and Jian [20], the strain enhancement ratio FRP confined concrete can be written:

For CFRP:

$$
\frac{\varepsilon_{c c}^{\prime}}{\varepsilon_{c o}^{\prime}}=2+17.41 \frac{f_{l u, a}^{\prime}}{f_{c o}^{\prime}}
$$

For GFRP:

$$
\frac{\varepsilon_{c c}^{\prime}}{\varepsilon_{c o}^{\prime}}=2+24.47 \frac{f_{l u, a}^{\prime}}{f_{c o}^{\prime}}
$$

Kwan and Dong [33] proposed a new Axial strength model for FRP confined concrete:

$$
\frac{\varepsilon_{c c}^{\prime}}{\varepsilon_{c o}^{\prime}}=1+17.4\left(\frac{\sigma_{r}}{f_{c}^{\prime}}\right)^{1.06}
$$

where $\sigma_{r}$ is the confining stress

\subsubsection{Proposed equation}

Fig. 11 illustrates the variation of the strain enhancement ratio for the effective confinement ratio of the present test data. Based on the test data shown in Fig. 11 the following equations are proposed for the axial strain at peak axial stress:

For CFRP confined concrete cylinders:

$$
\frac{\varepsilon_{c c}^{\prime}}{\varepsilon_{c o}^{\prime}}=2.11+15.8 \frac{f_{l, e f f}^{\prime}}{f_{c o}^{\prime}}
$$

For GFRP confined concrete cylinders:

$$
\frac{\varepsilon_{c c}^{\prime}}{\varepsilon_{c o}^{\prime}}=1.45+20.5 \frac{f_{l, e f f}^{\prime}}{f_{c o}^{\prime}}
$$

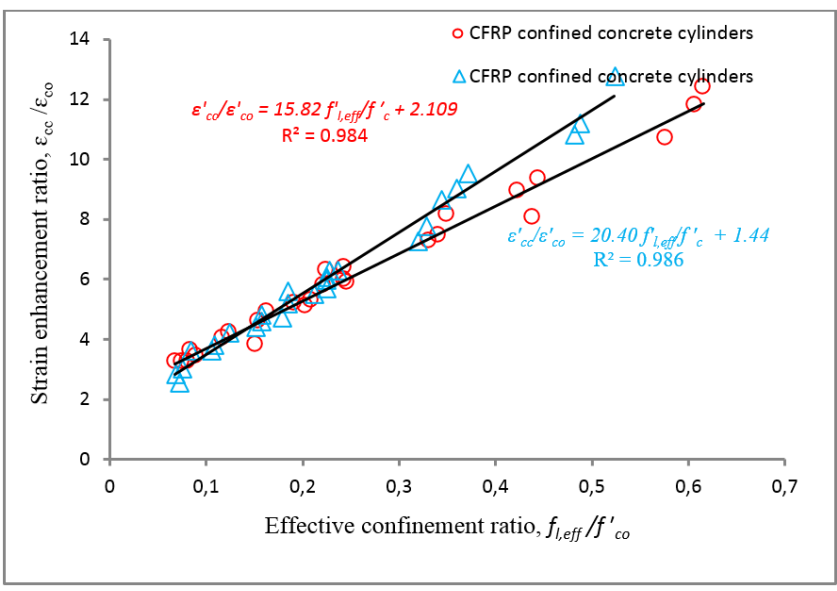

Fig. 11. Strain enhancement ratio vs. Effective confinement ratio

Replacing $f_{l, e f f}^{\prime}$ by $f_{l}^{\prime}$ in equations 27) and 28, using the mean effective FRP strain factor $k_{a e f}$, the ultimate axial strain of FRP confined concrete takes the forms:

For CFRP confined concrete cylinders:

$$
\frac{\varepsilon_{c c}^{\prime}}{\varepsilon_{c o}^{\prime}}=2.11+12.5 \frac{f_{l, e f f}^{\prime}}{f_{c o}^{\prime}}
$$


Tab. 3. Comparison of experimental and predicted results of CFRP confined concrete cylinders

\begin{tabular}{|c|c|c|c|c|c|c|c|c|c|c|c|c|c|}
\hline \multirow{2}{*}{ Source } & \multicolumn{8}{|c|}{ Experimental results } & \multicolumn{5}{|c|}{ Theoretical results } \\
\hline & $\begin{array}{c}D \\
(\mathrm{~mm})\end{array}$ & $\begin{array}{c}f_{c o}^{\prime} \\
(\mathrm{MPa})\end{array}$ & $\begin{array}{l}\varepsilon_{c o} \\
(\% \circ)\end{array}$ & $\begin{array}{c}E \\
(G P a)\end{array}$ & $\begin{array}{c}\varepsilon_{f r p u} \\
(\% \circ)\end{array}$ & $\begin{array}{c}t f \\
(\mathrm{~mm})\end{array}$ & $\begin{array}{c}f_{c c}^{\prime} \\
(\mathrm{MPa})\end{array}$ & $\begin{array}{l}\varepsilon_{c u} \\
(\% \circ)\end{array}$ & $\begin{array}{l}f_{l, \text { theo }}^{\prime} \\
\text { (MPa) }\end{array}$ & $\begin{array}{c}f_{c c}^{\prime} \\
(\mathrm{MPa})\end{array}$ & $\begin{array}{c}\varepsilon^{\prime} c c, t h e \\
(\% \circ)\end{array}$ & $\begin{array}{c}f_{\text {cctheo }}^{\prime} / \\
f_{\text {ccexp }}^{\prime}\end{array}$ & $\begin{array}{l}\varepsilon^{\prime} \text { ccthe } O \\
\varepsilon^{\prime} \text { 'ccexp }\end{array}$ \\
\hline \multirow{12}{*}{$\begin{array}{l}\text { Lam } \\
\text { and } \\
\text { Tang } \\
3\end{array}$} & 15 & 35.9 & 0.20 & 23 & 15 & 0.16 & 50.4 & 1.27 & 7.49 & 56.872 & 0.95 & 1.12 & 0.75 \\
\hline & 15 & 35.9 & 0.20 & 23 & 15 & 0.65 & 47.2 & 1.10 & 7.49 & 56.872 & 0.95 & 1.20 & 0.86 \\
\hline & 15 & 35.9 & 0.20 & 23 & 15 & 0.16 & 53.2 & 1.29 & 7.49 & 56.872 & 0.95 & 1.06 & 0.74 \\
\hline & 15 & 35.9 & 0.20 & 23 & 15 & 0.33 & 68.7 & 1.68 & 14.9 & 77.845 & 1.48 & 1.13 & 0.88 \\
\hline & 15 & 35.9 & 0.20 & 23 & 15 & 0.33 & 69.9 & 1.96 & 14.9 & 77.845 & 1.48 & 1.11 & 0.75 \\
\hline & 15 & 35.9 & 0.20 & 23 & 15 & 0.33 & 71.6 & 1.85 & 14.9 & 77.845 & 1.48 & 1.08 & 0.80 \\
\hline & 15 & 34.3 & 0.18 & 23 & 15 & 0.49 & 82.6 & 2.06 & 22.4 & 97.217 & 1.93 & 1.17 & 0.93 \\
\hline & 15 & 34.3 & 0.18 & 23 & 15 & 0.49 & 90.4 & 2.41 & 22.4 & 97.217 & 1.93 & 1.07 & 0.80 \\
\hline & 15 & 34.3 & 0.18 & 23 & 15 & 0.49 & 97.3 & 2.51 & 22.4 & 97.217 & 1.93 & 0.99 & 0.76 \\
\hline & 15 & 34.3 & 0.18 & 23 & 15 & 0.16 & 50.3 & 1.02 & 7.49 & 55.272 & 0.90 & 1.09 & 0.88 \\
\hline & 15 & 34.3 & 0.18 & 23 & 15 & 0.16 & 50 & 1.08 & 7.49 & 55.272 & 0.90 & 1.10 & 0.83 \\
\hline & 15 & 34.3 & 0.18 & 23 & 15 & 0.16 & 56.7 & 1.16 & 7.49 & 55.272 & 0.90 & 0.97 & 0.77 \\
\hline \multirow{6}{*}{$\begin{array}{c}\text { Valdmanis } \\
\text { et all } \\
18\end{array}$} & 15 & 40 & 0.17 & 23 & 10 & 0.17 & 66 & 0.63 & 5.30 & 54.851 & 0.63 & 0.83 & 1.01 \\
\hline & 15 & 40 & 0.17 & 23 & 10 & 0.34 & 87.2 & 1.07 & 10.608 & 69.702 & 0.92 & 0.79 & 0.86 \\
\hline & 15 & 40 & 0.17 & 23 & 10 & 0.51 & 96 & 1.36 & 15.9 & 84.554 & 1.20 & 0.88 & 0.88 \\
\hline & 15 & 44.3 & 0.17 & 23 & 10 & 0.17 & 73.3 & 0.58 & 5.30 & 59.151 & 0.61 & 0.80 & 1.05 \\
\hline & 15 & 44.3 & 0.17 & 23 & 10 & 0.34 & 82.6 & 0.54 & 10.6 & 74.002 & 0.86 & 0.89 & 1.60 \\
\hline & 15 & 44.3 & 0.17 & 23 & 10 & 0.51 & 115. & 0.94 & 15.9 & 88.854 & 1.12 & 0.77 & 1.19 \\
\hline \multirow{17}{*}{$\begin{array}{c}\text { Vincent } \\
\text { and } \\
\text { Ozbakkaloglu } \\
19\end{array}$} & 15 & 35.5 & 0. & 24 & 16 & 0.11 & 44 & 0.77 & 5.91 & 52.052 & 0.83 & 1.18 & 1.08 \\
\hline & 15 & 35.5 & 0. & 24 & 16 & 0.11 & 43.9 & 0.82 & 5.91 & 52.052 & 0.83 & 1.18 & 1.02 \\
\hline & 15 & 35.5 & 0. & 24 & 16 & 0.11 & 43.1 & 0.82 & 5.91 & 52.052 & 0.83 & 1.20 & 1.02 \\
\hline & 15 & 38 & 0.21 & 24 & 16 & 0.23 & 63.5 & 1.51 & 11.8 & 71.105 & 1.25 & 1.12 & 0.83 \\
\hline & 15 & 38 & 0.21 & 24 & 16 & 0.23 & 66.1 & 1.65 & 11.8 & 71.105 & 1.25 & 1.07 & 0.76 \\
\hline & 15 & 36.1 & 0. & 24 & 16 & 0.23 & 58.6 & 1.27 & 11.8 & 69.205 & 1.23 & 1.18 & 0.97 \\
\hline & 15 & 64.5 & 0.27 & 24 & 16 & 0.11 & 65.6 & 0.59 & 5.91 & 81.052 & 0.87 & 1.23 & 1.48 \\
\hline & 15 & 64.5 & 0.27 & 24 & 16 & 0.11 & 68.7 & 0.57 & 5.91 & 81.052 & 0.87 & 1.18 & 1.53 \\
\hline & 15 & 62.9 & 0.27 & 24 & 16 & 0.11 & 66.3 & 0.65 & 5.91 & 79.452 & 0.88 & 1.19 & 1.36 \\
\hline & 15 & 64.5 & 0.27 & 24 & 16 & 0.23 & 72.3 & 0.93 & 11.8 & 97.605 & 1.18 & 1.35 & 1.27 \\
\hline & 15 & 62.4 & 0.27 & 24 & 16 & 0.23 & 68.4 & 0.71 & 11.8 & 95.505 & 1.20 & 1.39 & 1.69 \\
\hline & 15 & 64.2 & 0.27 & 24 & 16 & 0.23 & 68.2 & 0.82 & 11.8 & 97.305 & 1.18 & 1.42 & 1.44 \\
\hline & 15 & 64.5 & 0.27 & 24 & 16 & 0.35 & 85.9 & 1.19 & 17.7 & 114.16 & 1.49 & 1.32 & 1.25 \\
\hline & 15 & 64.5 & 0.27 & 24 & 16 & 0.35 & 80.3 & & 17.7 & 114.16 & 1.49 & 1.42 & 1.49 \\
\hline & 15 & 64.5 & 0.27 & 24 & 16 & 0.46 & 99.4 & 1.38 & 23.6 & 130.71 & 1.80 & 1.31 & 1.30 \\
\hline & 15 & 62.4 & 0.27 & 24 & 16 & 0.46 & 101. & 1.41 & 23.646 & 128.61 & 1.84 & 1.27 & 1.30 \\
\hline & 15 & 65.8 & 0.27 & 24 & 16 & 0.46 & 104. & 1.36 & 23.646 & 132.01 & 1.78 & 1.26 & 1.30 \\
\hline \multicolumn{9}{|c|}{ Moye } & & & & 1.12 & 1.07 \\
\hline \multicolumn{9}{|c|}{ Standard Deviation } & & & & 0.17 & 0.28 \\
\hline \multicolumn{9}{|c|}{ Coefficient of variation (\%) } & & & & 15.2 & 26.7 \\
\hline
\end{tabular}


Tab. 4. Comparison of experimental and predicted results of GFRP confined concrete cylinders

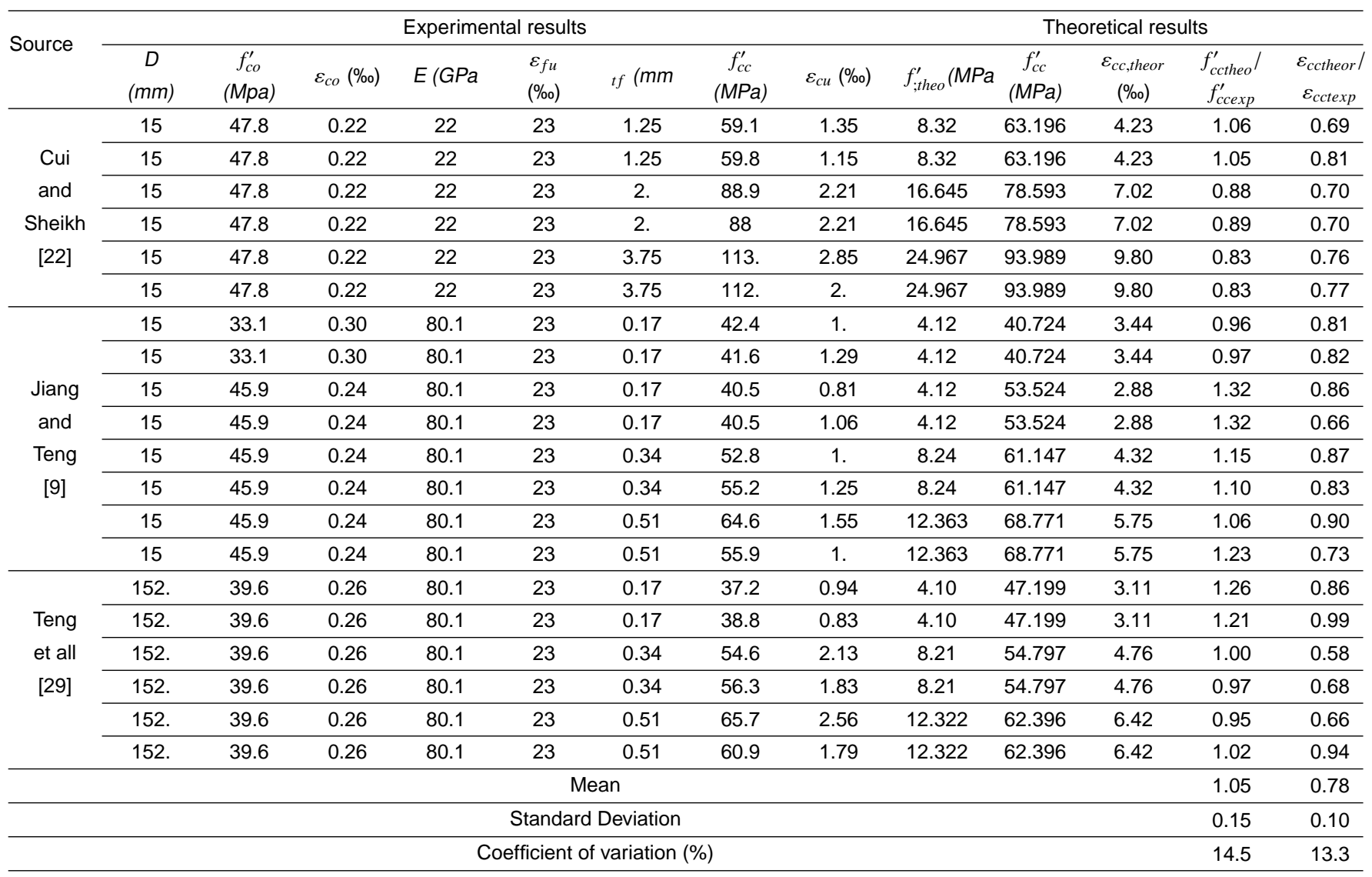

For GFRP confined concrete cylinders:

$$
\frac{\varepsilon_{c c}^{\prime}}{\varepsilon_{c o}^{\prime}}=1.45+15 \frac{f_{l, e f f}^{\prime}}{f_{c o}^{\prime}}
$$

\subsection{Validation of the proposed model}

The strength and strain enhancement proposed model of FRP confined concrete cylinders is compared to the test data obtained by [3, 18, 19], and [9, 22, 29], as shown in Table 3 and Table 4 . on CFRP and GFRP confined concrete cylinders, respectively.

These comparisons indicate that the prediction model is in agreement with the test results, which are countrified during the use of statistical indicators: mean (M) to establish average overestimation or underestimation of the model; standard deviation (SD) to establish the magnitude of the associated scatter; and coefficient of variation (CV) a measure of dispersion. These parameters prove, for confined concrete cylinders, a good correlation between the analytical predictions of the proposed model with the experimental results of an independent test series.

\section{Conclusions}

A total of 54 FRP wrapped concrete cylinders were subjected to monotonic axial compression. Three concrete batches (low, normal and high strength), three different numbers of wraps and two types of FRP (CFRP and GFRP wraps) were investigated. The enhancement of strength and ductility of FRP confined concrete cylinders is significant. The improvement in stress and strain is dependent on the type of FRP composite wraps, unconfined concrete strength and the number of reinforcement layers.

The following conclusions may be drawn from this study are:

1 The strength and strain capacities of the specimens wrapped with FRP materials are greatly improved compared to the unconfined concrete cylinders;

2 Failure of all confined concrete cylinders is marked by the rupture of FRP materials, it occurs prematurely. The ultimate strain of the wraps is much lower than the rupture strain obtained from tensile coupon test;

3 The observed stress-strain response of FRP confined concrete cylinders can be divided in three different zones. The first zone is approximately linear corresponding to the passive form of FRP material and the second zone is nonlinear as a transition zone. In the third zone, the FRP confinement is activated to provide additional load-carrying capacity;

4 The test results indicate that the Carbone FRP confined concrete specimens has significantly better results compared to the glass FRP case;

5 The confinement effectiveness decreases with the increase of unconfined concrete strength, the same FRP amount led to an increase of compressive strength by about $69 \%, 40 \%$ and $31 \%$, respectively for low, normal and high of unconfined concrete strength; 


\begin{tabular}{|c|c|c|c|}
\hline \multicolumn{4}{|c|}{ Nomenclature } \\
\hline$f_{c o}^{\prime}$ & $\begin{array}{l}\text { ultimate strength of unconfined } \\
\text { concrete }\end{array}$ & $E_{f r p}$ & tensile modulus of FRP \\
\hline$f^{\prime} c c$ & $\begin{array}{l}\text { ultimate strength of FRP confined } \\
\text { concrete }\end{array}$ & $\rho_{f r p}$ & FRP volumetric ratio \\
\hline$f_{l}^{\prime}$ & effective lateral confining stress & $k_{e f}$ & effective FRP strain factor \\
\hline$\varepsilon_{c o}$ & $\begin{array}{l}\text { ultimate strain of unconfined } \\
\text { concrete }\end{array}$ & $k_{m e f}$ & mean effective FRP strain factor \\
\hline$\varepsilon^{\prime} c$ & $\begin{array}{l}\text { ultimate strain of FRP confined } \\
\text { concrete }\end{array}$ & $\varnothing$ & angle of internal friction of concrete \\
\hline$\varepsilon_{f r p, u}$ & $\begin{array}{l}\text { ultimate circumferential strain in } \\
\text { the composite jacket }\end{array}$ & $t_{f}$ & Thickness of FRP composite \\
\hline$\varepsilon_{h, \text { rep }}$ & $\begin{array}{l}\text { effective failure strain of FRP } \\
\text { confined concrete }\end{array}$ & $D$ & diameter of the concrete core \\
\hline
\end{tabular}

6 The ultimate strengths and strains increase significantly with the enhancement of the number of composite layers, but the effect is not directly proportional to the number of layers;

7 The confinement with FRP materials produced a tri-axial stress field in concrete, which results in the improvement of the compressive strength, maximum stress and strain. Based on the observed experimental results a new compressive strength model is proposed. This model prove that the ultimate capacity of the FRP confined concrete cylinders, given in terms of ultimate strength and axial strain, depends on the effective confinement pressure at failure and on the unconfined concrete core strength. A good agreement was obtained between experimental and proposed model results.

\section{Acknowledgement}

Authors thankfully acknowledge the support of Sika-Algérie for providing the FRP materials.

\section{References}

1 Spoelstra M, Monti G, FRP-confined Concrete Model, Journal of Composites for Construction (ASCE), 3, (1999), 143-150, DOI 10.1061/(ASCE)1090-0268(1999)3:3(143)

2 Bouchelaghem H, Bezazi A, Scarpa F, Compressive behaviour of concrete cylindrical FRP-confined columns subjected to a new sequential loading technique, Composites Part B: Engineering, 42, (2011), 1987-1993, DOI 10.1016/j.compositesb.2011.05.045

3 Lam L, Teng JG, Ultimate condition of FRP-confined concrete, Journal of Composites for Construction (ASCE), 8, (2004), 539-548, DOI 10.1061/(ASCE)1090-0268(2004)8:6(539)

4 Scholefield BWJ, The strengthening of reinforced concrete columns with various methods, M.Sc. Thesis. Department of Civil Engineering, University of Calgary; Calgary, Alberta, Canada, September, 2003.

5 Goodman RE, Introduction to Rock Mechanics, John Wiley \& Sons, 1989.

6 Lam L, Teng J, Strength Models for Fiber-reinforced Plastic Confined Concrete, Journal of Structural Engineering (ASCE), 128, (2002), 612-623, DOI 10.1061/(ASCE)0733-9445(2002)128:5(612)

7 Lam L, Teng JG, Design-oriented Stress-Strain Model for FRP Confined Concrete, Construction and Building Materials, 17, (2003), 471-489, DOI 10.1016/S0950-0618(03)00045-X
8 Ozbakkaloglu T, Compressive behaviour of concrete-filled FRP tube columns: Assessment of critical column parameters, Engineering Structures, 51, (2013), 188-199, DOI 10.1016/j.engstruct.2013.01.017

9 Jiang T, Teng J, Analysis-oriented Stress-Strain Models for FRPConfined Concrete, Engineering Structures, 29, (2007), 2968-2986, DOI 10.1016/j.engstruct.2007.01.010

10 Tao Z, Yu Q, Zhong Y-Z, Compressive behaviour of CFRP confined rectangular concrete columns, Magazine of Concrete Research, 60, (2008), 735745, DOI 10.1680/macr.2007.0011

11 Nisticò N, Pallini F, Rousakis T, Wu Y, Karabinis A, Peak strength and ultimate strain prediction for FRP confined square and circular concrete sections, Composites Part B: Engineering B, 67, (2014), 543-554, DOI 10.1016/j.compositesb.2014.07.026

12 Micelli F, Modarelli R, Experimental and analytical study on properties affecting the behaviour of FRP-confined concrete, Composites Part B: Engineering, 45, (2013), 1420-1431, DOI 10.1016/j.compositesb.2012.09.055

13 Li Y, Chih L, Yi S A, Constitutive model for concrete confined with carbon fiber reinforced plastics, Mechanics of Materials, 35, (2003), 603-619, DOI 10.1016/S0167-6636(02)00288-0

14 Afifi MZ, Mohamed HM, Benmokrane B, Theoretical stressstrain model for circular concrete columns confined by GFRP spirals and hoops, Engineering Structures, 102, (2015), 202-213, DOI 10.1016/j.engstruct.2015.08.020

15 Shahawya M, Mirmiranb T, Beitelman T, Tests and modeling of carbonwrapped concrete columns, Composites Part B: Engineering, 31, (2000), 471-480.

16 Köroğlu M, Ceylan M, Arslan M, İlki A, Estimation of flexural capacity of quadrilateral FRP-confined RC columns using combined artificial neural network, Engineering Structures, 42, (2012), 23-32, DOI 10.1016/j.engstruct.2012.04.013

17 Hussein M, Elsanadedy Y, Al-Salloum A, Saleh H, Alsayed A, $E x$ perimental and numerical investigation of size effects in FRP-wrapped concrete columns, Construction and Building Materials, 29, (2012), 56-72, DOI 10.1016/j.conbuildmat.2011.10.025

18 Valdmanis V, DeLorenzis L, Rousakis T, Tepfers R, Behaviour and capacity of CFRP-confined concrete cylinders subjected to monotonic and cyclic axial compressive load, Structural Concrete Journal, 8(4), (2007), 187190.

19 Vincent T, Ozbakkaloglu T, Influence of concrete strength and confinement method on axial compressive behaviour of FRP confined high-and ultra high-strength concrete, Composites Part B: Engineering, 50, (2013), 413-428, DOI 10.1016/j.compositesb.2013.02.017

20 Ozbakkaloglu T, Jian C, Axial compressive behaviour of FRPconfined concrete: Experimental test database and a new design-oriented 
model, Composites Part B: Engineering, 55, (2013), 607-634, DOI 10.1016/j.compositesb.2013.07.025

21 Mirmiran A, A new concrete-filled hollow FRP composite column, Composites Part B: Engineering, 27, (1996), 263-268.

22 Cui C, Sheikh A, Experimental study of normal- and high-strength concrete confined with fiber-reinforced polymers, Journal of Composites for Construction (ASCE), 14, (2010), 553-561, DOI 10.1061/(ASCE)CC.19435614.0000116

23 Shehata I, Carneiro L, Shehata L, Strength of Short Concrete Columns Confined with CFRP Sheets, Materials and Structures, 35, (2002), 50-58, DOI $10.1007 / \mathrm{BF} 02482090$

24 Teng J, Jiang T, Lam L, Luo Y, Refinement of a design-oriented stressstrain model for FRP-confined concrete, Journal of Composites for Construction (ASCE), 13(4), (2009), 269-278, DOI 10.1061/(ASCE)CC.19435614.0000012

25 Bieniawski Z, Estimating the strength of rock materials, Journal of the south african institute of mining and metallurgy, 74, (1974), 312-324.

26 Realfonzo R, Napoli A, Concrete confined by FRP systems: confinement efficiency and design strength models, Composites Part B: Engineering, 42(4), (2011), 736-55, DOI 10.1016/j.compositesb.2011.01.028

27 Rousakis T, Nistico N, Karabinis A, Upgraded experimental database of uniformly FRP confined concrete columns for assessment of existing recommendations, In: Monti $\mathbf{J}$ (ed.), The 6th international conference on FRP composites in civil engineering - CICE 2012; Rome, 13-15 of June 2012.

28 Mohamed H, Masmoudi R, Axial load capacity of concrete-filled FRP tube columns: experimental versus predictions, Journal of Composites for Construction (ASCE), 14, (2010), 231-243, DOI 10.1061/(ASCE)CC.19435614.0000066

29 Teng JG, Yu T, Wong YL, Dong S, Hybrid FRP-concrete-steel tubular columns: concept and behaviour, Construction and Building Materials, 21(4), (2007), 846-854, DOI 10.1016/j.conbuildmat.2006.06.017

30 Saadatmanesh H, Ehsani MR, Li MW, Strength and Ductility of Concrete Columns Externally Reinforced with Composites Straps, Aci Structural Journal, 91, (1994), 434-447, DOI 10.14359/4151

31 Richart F, Brandtzaeg A, Brown R, The Failure of Plain and Spirally Reinforced Concrete in Compression, Bulletin No.190, Engineering Experiment Station, University of Illinois; Urbana, USA, 1929.

32 Manuel A, Silva G, Behaviour of square and circular columns strengthened with aramidic or carbon fibers, Construction and Building Materials, 25, (2011), 3222-3228, DOI 10.1016/j.conbuildmat.2011.03.007

33 Kwan AKH, Dong CX, Axial and lateral stress-strain model for FRP confined concrete, Engineering Structures, 99, (2015), 285-295, DOI 10.1016/j.engstruct.2015.04.046

34 Pham T X, Hadi M, Confinement model for FRP confined normal- and highstrength concrete circular columns, Construction and Building Materials, 69 , (2014), 83-90, DOI 10.1016/j.conbuildmat.2014.06.036

35 Fardis MN, Khalili H, FRP-encased Concrete as a Structural Material, Magazine of Concrete Research, 34, (1982), 191-202.

36 Mander JB, Priestley M, Park R, Theoretical stress-strain model for confined concrete, Journal of Structural Engineering (ASCE), 114, (1988), 18041826, DOI 10.1061/(ASCE)0733-9445(1988)114:8(1804)

$37 \mathbf{W u} \mathbf{Y}-\mathbf{F}$, Jiang J-F, Effective strain of FRP for confined circular concrete columns, Composite Structures, 95, (2013), 479-491, DOI 10.1016/j.compstruct.2012.08.021

38 Monti G, Nistico N, Square and rectangular concrete columns confined by CFRP: experimental and numerical investigation, Mechanics of Composite Materials, 44(3), (2008), DOI 10.1007/s11029-008-9021-1 